\title{
Profile of Cultural Intelligence of Students in Sumbawa District
}

\author{
${ }^{1 *}$ Suharli, ${ }^{2}$ Nining Andriani, ${ }^{3}$ I Gusti Made Sulindra, ${ }^{4}$ I Made Sentaya \\ ${ }^{1,2}$ Economic Education Department, ${ }^{3,4}$ Teknology Education Departement, Faculty of Teacher \\ Education, Universitas Samawa. J1. Bay Pass Sering Sumbawa Besar, Indonesia. Postal code:
} 84316

*Corresponding Author e-mail: 5uharli.uns4@gmail.com

Received: July 2021; Revised: September 2021; Published: December 2021

\begin{abstract}
This study aims to examine the profile of cultural intelligence of junior high school students in Sumbawa district. The sample in this study amounted to 450 junior high school students in Sumbawa-NTB district. Descriptive statistics were used to determine the level of cultural intelligence of the students in this study. The level of cultural intelligence of students is reflected in the percentage of respondents' answers to each indicator of cultural intelligence. The research instrument used a questionnaire. Test the validity and reliability of the questionnaire using IMB SPSS 26 statistics. Meanwhile, data analysis to determine the level of cultural intelligence of students was analyzed manually using the percentage formula. The results showed that from the 20 questionnaire items there were 17 items that were declared valid with a reliability level of 0.86 . Furthermore, the level of cultural intelligence of students on the metacognitive indicator obtained a score of $75.63 \%$, on the cognitive indicator a score of $57.96 \%$, on the motivation indicator a score of $64.80 \%$, on the behavioral indicator a score of $66.83 \%$, and the total average score of $66.31 \%$. Thus, it is hoped that teachers and school principals can use the cultural intelligence of students as a reference in designing and implementing the learning process in the classroom.
\end{abstract}

Keywords: cultural intelligence, students, SMP

How to Cite: Suharli, S., Andriani, N., Sulindra, I., \& Sentaya, I. (2021). Profile of Cultural Intelligence of Students in Sumbawa District. Prisma Sains : Jurnal Pengkajian Ilmu dan Pembelajaran Matematika dan IPA IKIP Mataram, 9(2), 177-185. doi:https://doi.org/10.33394/j-ps.v9i2.4214

https://doi.org/10.33394/j-ps.v9i2.4214

Copyright@ 2021, Suharli et al This is an open-access article under the CC-BY License.

\section{INTRODUCTION}

Cultural intelligence is a special form of "multiple intelligence" that requires individuals who focus more on the ability to understand the conditions of cultural diversity (James, M, \& Wulandari, M., P, 2014). Cultural intelligence is the cognitive, motivational, and behavioral capacity to understand effectively in responding to people's beliefs, values, attitudes, and behaviors in complex and ever-changing situations (Mansuri et al., 2014).

In today's global conditions, educational institutions do not only focus on developing the traditions, disciplines of knowledge, abilities, and skills of graduates, but must ensure that graduates also acquire what is often called cultural intelligence (Smith et al., 2010). The field of education is one of the fields of research that is very relevant for developing cultural intelligence (CQ). Cultural intelligence (CQ) can be learned and taught and is a very important skill to have today. Cultural intelligence (CQ) should be introduced as part of the curriculum and should be one of the cross-cultural management skills and competencies required in today's workplace (Menon \& Narayanan, 2015). Cultural intelligence promotes a learning model in which each student contributes according to cultural abilities and performs in their own way. As a result, students are more confident, no one looks down on them because they do things differently and learn to be better (Ramis \& Krastina, 2010). 
In the current global context, Sumbawa is one of ten regencies/cities in West Nusa Tenggara Indonesia with a very diverse society (Iskandar, 2013). Based on the conditions of ethnic diversity and cultural differences in Sumbawa, cultural intelligence is a competency that must be taught to students. Teachers currently including in Sumbawa, often face some challenges in teaching students from various ethnicities. Thus, the teachers must be able to develop their understanding, beliefs, and expectations about how to teach students from diverse communities and families (Suharli et al., 2019). Students with high cultural intelligence allow themselves to communicate in a more sensitive way and be able to show responses according to the behavior of other people from different cultural backgrounds. The concept of cultural intelligence is very significant, especially for the context of classrooms or schools in the multicultural Sumbawa community. In contemporary education, especially in schools, class diversity makes all teachers work or (will work) with students from various cultural backgrounds (Suharli et al., 2019).

The learning process carried out by the teacher must lead to efforts to foster cultural intelligence, namely the ability of students to function effectively in multi-cultural situations. The development of cultural awareness possessed by teachers ensures that culturally and linguistically diverse learners receive culturally responsive practices. Culturally responsive teachers seek to understand students and their families, respect differences, work towards fair and disciplined classrooms, develop social skills and awareness of others' ideas, build a community of learners, and set high expectations for all (Moore, 2018). Teachers must be able to develop superior cultural intelligence, which will help in developing tolerance and interaction of students from different ethnicities and cultures. Cultural diversity can be a source of conflict. Ethnic, cultural and religious diversity used to be the cause of conflict in society. Therefore, cultural intelligence is an indispensable competency, including the multi ethnic Sumbawa community (Suharli et al., 2021).

One learning model that is suitable to be applied to the characteristics of learning in instilling the value of tolerance is a learning model that is characterized by an increase in creative and critical thinking skills and a learning process that must provide opportunities for all students to develop their potential so that the learning process will direct students to be active with experience. students themselves (Gustina et al., 2019). As the school population becomes increasingly diverse with students from different ethnic, cultural and linguistic backgrounds, there is a need to implement more responsive learning by leveraging the cultural capital of these students into the learning process (Wachira \& Mburu, 2017). Thus, to make it easier for teachers to design and implement the learning process in the classroom so that tolerance between students can be increased, the purpose of this study is to obtain an initial picture of the profile of cultural intelligence possessed by students. Furthermore, the cultural intelligence profile of students can be used as a reference for teachers in choosing the right learning strategies and methods. Profiles of cultural intelligence of students can help teachers, especially in accommodating ethnic diversity and cultural differences of students in learning activities.

\section{METHOD}

This study is a quantitative descriptive study. This research was conducted at 27 junior high schools in three zones of Sumbawa-NTB Regency, namely 9 SMP representing schools in the western region, 9 SMP representing schools in the middle, and 9 SMP representing schools in the east. The number of respondents who became subjects in this study amounted to 450 students consisting of 250 female students and 200 male students. The instrument used to measure the cultural intelligence profile of students using a cultural intelligence questionnaire that has been developed by (Ang et al., 2007) was then adapted and revised according to the needs and context of students in Sumbawa Regency (Table 1). Test the validity and reliability of the questionnaire using IBM SPSS statistics version 26 (Table 1). Meanwhile, to determine the percentage of students' cultural intelligence levels on each 
cultural intelligence indicator, they were analyzed manually using the percentage formula bellow.

$$
\%=\frac{\text { scquisition score }}{\text { maximal scor }} X 100
$$

Table 1. Cultural Intelligence Questionnaire

\section{CQ-Metacognitive}

1. I understand what I can and can't do when interacting with people of other ethnicity

\begin{tabular}{|l|l|l|l|l|l|l|l|}
\hline 1 & Very understanding & 2 & Understanding & 3 & $\begin{array}{l}\text { Fairly } \\
\text { understanding }\end{array}$ & 4 & $\begin{array}{l}\text { Not } \\
\text { understanding }\end{array}$ \\
\hline
\end{tabular}

2. I understand what I should do if I interact with people who different culture with me.

\begin{tabular}{|l|l|l|l|l|l|l|l|}
1 & Very understand & 2 & Understand & 3 & $\begin{array}{l}\text { Sufficiently } \\
\text { understand }\end{array}$ & 4 & $\begin{array}{l}\text { Don't } \\
\text { understand }\end{array}$ \\
\hline
\end{tabular}

3. I learn about behavior and way of life in other ethnic communities.

\begin{tabular}{l|l|l|l|l|l|l|l}
1 & Always & 2 & Sometimes & 3 & Rarely & 4 & Never \\
\hline
\end{tabular}

\section{CQ-Cognitive}

1. I know about the differences and similarities in the customary law of the existing ethnic groups.

\begin{tabular}{l|l|l|l|l|l|l|l}
1 & Very knowing & 2 & Knowing & 3 & enough & 4 & Not knowing
\end{tabular}

2. I know the cultural values and beliefs/religions of other cultures.

\begin{tabular}{|l|l|l|l|l|l|l|l|}
\hline 1 & Very knowledgeable & 2 & Knowing & 3 & $\begin{array}{l}\text { Fairly } \\
\text { knowing }\end{array}$ & 4 & Don't know \\
\hline
\end{tabular}

3. I am aware of other ethnic marriage systems.

\begin{tabular}{|l|l|l|l|l|l|l|l|}
\hline 1 & Very knowledgeable & 2 & Knowing & 3 & enough & 4 & Not knowing \\
\hline
\end{tabular}

4. I know the arts of other ethnicities.

\begin{tabular}{l|l|l|l|l|l|l|l|}
\hline 1 & Very knowing & 2 & Knowing & 3 & enough & 4 & Not knowing \\
\hline 5.
\end{tabular}

5 . I know the meaning of each expression of behavior in other cultures.

\begin{tabular}{|l|l|l|l|l|l|l|l|}
\hline 1 & Very knowledgeable & 2 & Knowing & 3 & $\begin{array}{l}\text { Fairly } \\
\text { knowing }\end{array}$ & 4 & Don't know \\
\hline
\end{tabular}

\section{CQ-Motivation}

1. I enjoy interacting with people of different ethnicity with me.

\begin{tabular}{|l|l|l|l|l|l|l|l}
\hline 1 & Very much enjoyed & 2 & Enjoyed & 3 & Quite enjoyed & 4 & Not enjoyed \\
\hline 2
\end{tabular}

2. I am sure that I can socialize with other ethnic groups that I just met.

\begin{tabular}{l|l|l|l|l|l|l|l}
1 & Very sure & 2 & Sure & 3 & Quite sure & 4 & Not sure
\end{tabular}

3. I feel confident that I can adapt to other ethnic groups that I have just met

\begin{tabular}{l|l|l|l|l|l|l|l|}
1 & Very sure & 2 & Sure & 3 & Fairly sure & 4 & Not sure
\end{tabular}

4. I enjoy living with ethnicities I am not familiar with.

\begin{tabular}{l|l|l|l|l|l|l|l|}
\hline 1 & Very much enjoyed & 2 & Enjoyed & 3 & moderately & 4 & Not enjoyed
\end{tabular}

5. I am sure that I will get used to different cultural conditions.
1 Very sure
2 Sure
3 Quite sure
4 Not sure

CQ-Behavior

1. I change my verbal behavior (gestures, tone of voice) when I interact with people of a different ethnicity to me.
1 Always
2 Sometimes
3 Rarely
4 Never

2. I prefer to remain silent when I adjust to people from different cultures from mine.

\begin{tabular}{l|l|l|l|l|l|l|l|}
\hline 1 & Always & 2 & Sometimes & 3 & Rarely & 4 & Never \\
\hline
\end{tabular}

3. I change my speech when interacting in different cultural situations.

\begin{tabular}{l|l|l|l|l|l|l|l}
1 & Always & 2 & Sometimes & 3 & Rarely & 4 & Never
\end{tabular}

4. I change my behavior when interacting in different cultural situations
1 Always
\begin{tabular}{l|l|l|l|}
2 & Sometimes & 3 & Rarely
\end{tabular}
4 Never 


\section{Questionnaire Validity and Reliability Test Results}

Based on the results of the data analysis of the questionnaire validity test given to 31 respondents with 20 questionnaire items, 17 questionnaire items were declared valid. While the reliability of the questionnaire obtained data of 0.86 alpha Cronbach. Thus, the questionnaire data can be said to be very reliable. Test data validity and reliability of the questionnaire as follows (Table 2 and Table 3 ).

Table 2. Instrument Validity

\begin{tabular}{cccc}
\hline No. Item & rxy & rtabel & Description \\
\hline 1 & 0.075 & 0.355 & Invalid \\
2 & 0.408 & 0.355 & Valid \\
3 & 0.568 & 0.355 & Valid \\
4 & 0.453 & 0.355 & Valid \\
5 & 0.478 & 0.355 & Valid \\
6 & 0.305 & 0.355 & Invalid \\
7 & 0.603 & 0.355 & Valid \\
8 & 0.685 & 0.355 & Valid \\
9 & 0.492 & 0.355 & Valid \\
10 & 0.705 & 0.355 & Valid \\
11 & 0.428 & 0.355 & Valid \\
12 & 0.642 & 0.355 & Valid \\
13 & 0.479 & 0.355 & Valid \\
14 & 0.598 & 0.355 & Valid \\
15 & 0.483 & 0.355 & Valid \\
16 & 0.576 & 0.355 & Valid \\
17 & 0.525 & 0.355 & Valid \\
18 & 0.742 & 0.355 & Valid \\
19 & 0.487 & 0.355 & Valid \\
20 & 0.345 & 0.355 & Invalid \\
\hline
\end{tabular}

Table 3. Instrument reliability

\begin{tabular}{cc}
\hline \multicolumn{2}{c}{ Reliability Statistics } \\
\hline Cronbach's Alpha & N of Item \\
\hline 0.86 & 17 \\
\hline
\end{tabular}

\section{RESULTS AND DISCUSSION}

Based on the results of data analysis on metacognitive indicators of cultural intelligence (CQ), information was obtained that most of the students had a fairly high level of cultural intelligence. This means that most students have an awareness of the cultural differences they have with other people. Referring to such conditions, the social studies learning process must be able to be utilized to increase maximum results on the level of cultural intelligence of students on metacognitive indicators. The results show that the cultural intelligence profile of students is reflected in the following Figure 1. 


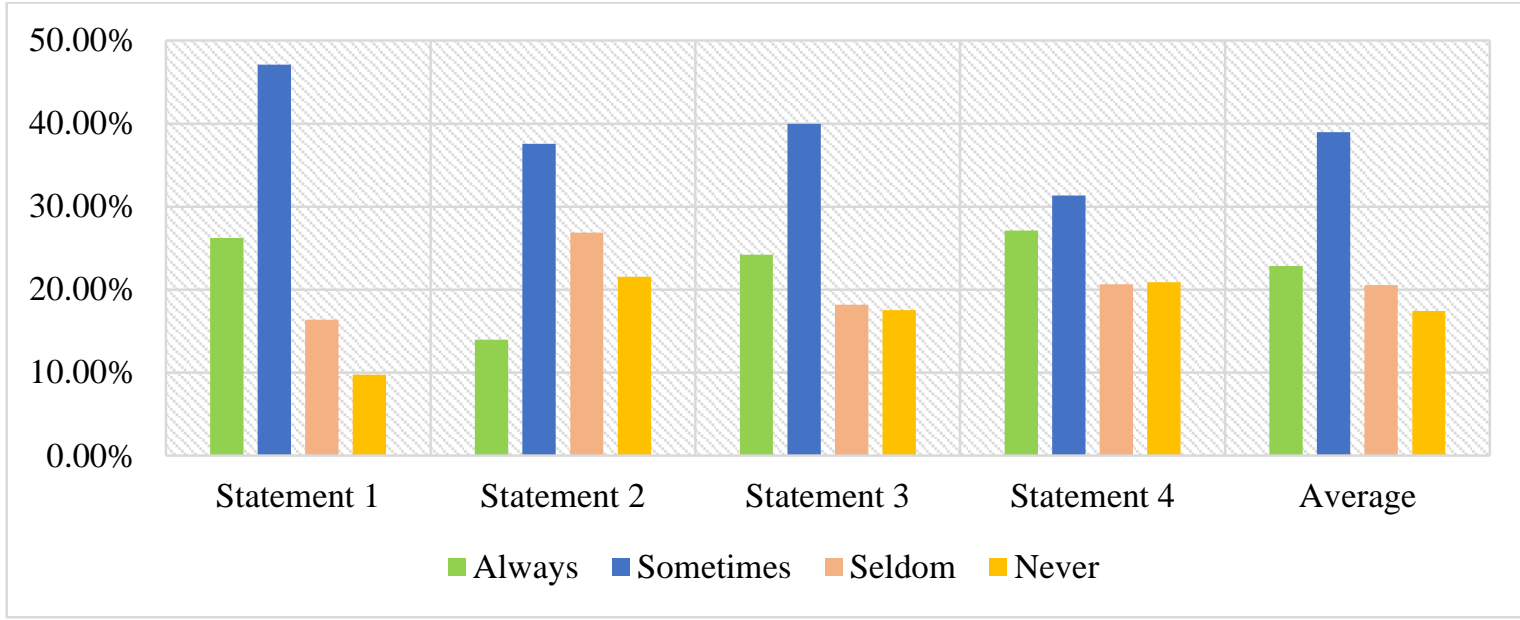

Figure 1. Metacoqnitive CQ

Next the data obtained on the cognitive indicators of CQ, most students have a better level of understanding of the culture of other people around them. It can be concluded that students quite understand the conditions and cultural backgrounds of other students so that social studies teachers can use them to maximize interaction patterns between students of different religions and cultures at in class. Thus, the process and results of social studies learning can be achieved well by the teacher by paying attention to the abilities and initial understanding of students towards other students. Furthermore, the cognitive indicators of CQ obtained information as listed in the graph as follows (Figure 2).

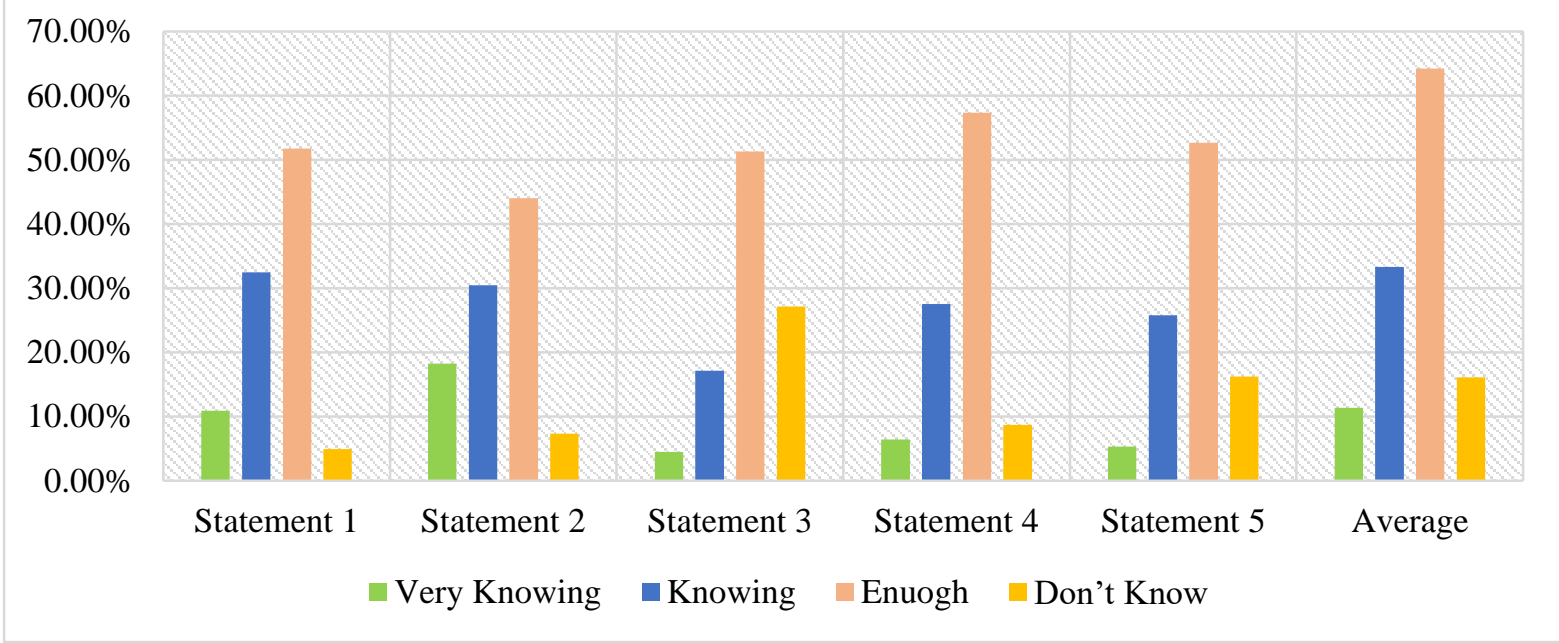

Figure 2. Cognotive CQ

In the CQ motivation indicator it isthat most of the students have not been motivated and enjoy the process of interaction with other students from different religious and cultural backgrounds. That is, through the social studies learning process, teachers need to design learning that allows interaction between students of different religions and cultures in the classroom. In addition, the learning design needs to be packaged in the form of group discussions that place students actively involved in the collaboration process with other students optimally and present some of the actual problems that occur in the community to be solved together through heterogeneous group discussions. Thus, through direct involvement, students can encourage the willingness to mingle and enjoy working with other students who are religiously and culturally different. 


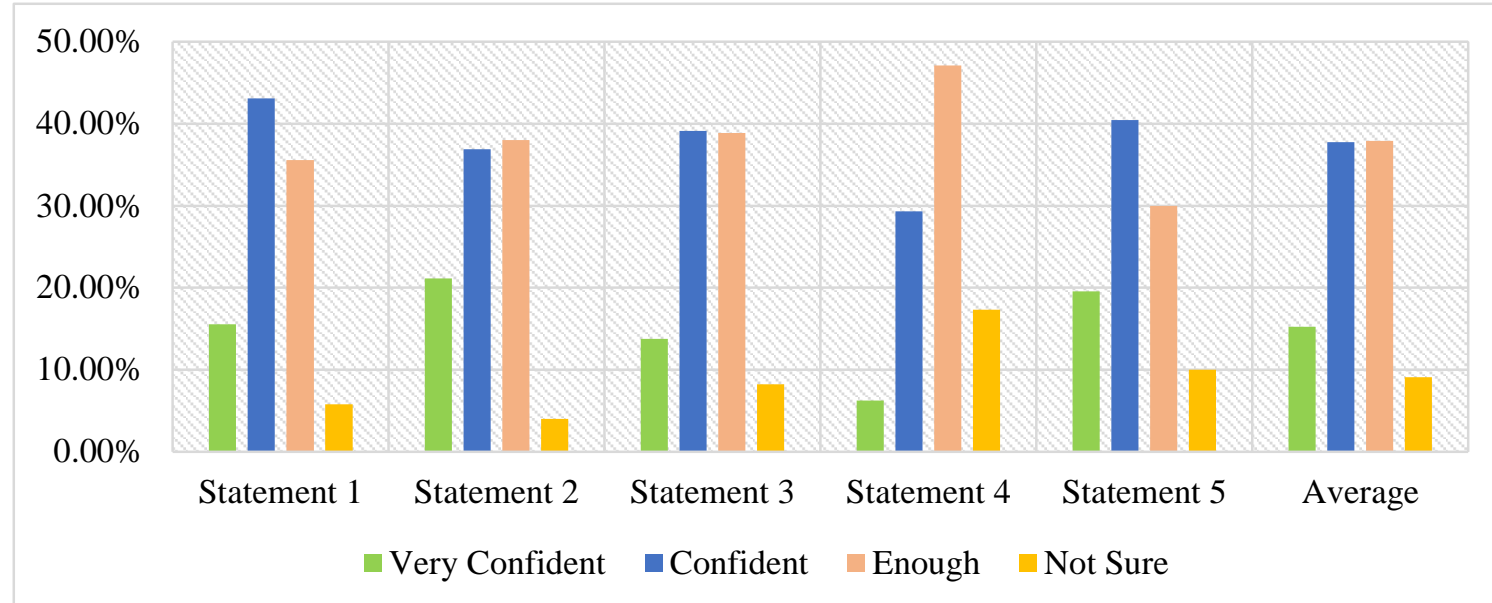

Figure 3. Motivation of CQ

Based on the data on the CQ behavior indicators, most of the students always change their oral behavior when interacting with people from different ethnicities, always choose to remain silent when adjusting to the environment. people from different cultures, always change the way they talk when interacting in situations of different cultures, always change their behavior when interacting in different cultural situations. This means that the cultural intelligence of students on this indicator still needs to be improved so that the interaction and communication process between students who are religiously and culturally different can run better. Thus, through the social studies learning process, it is expected to involve students in heterogeneous group activities and to be involved in field tasks that allow interaction between students and communities that are religiously and culturally different.

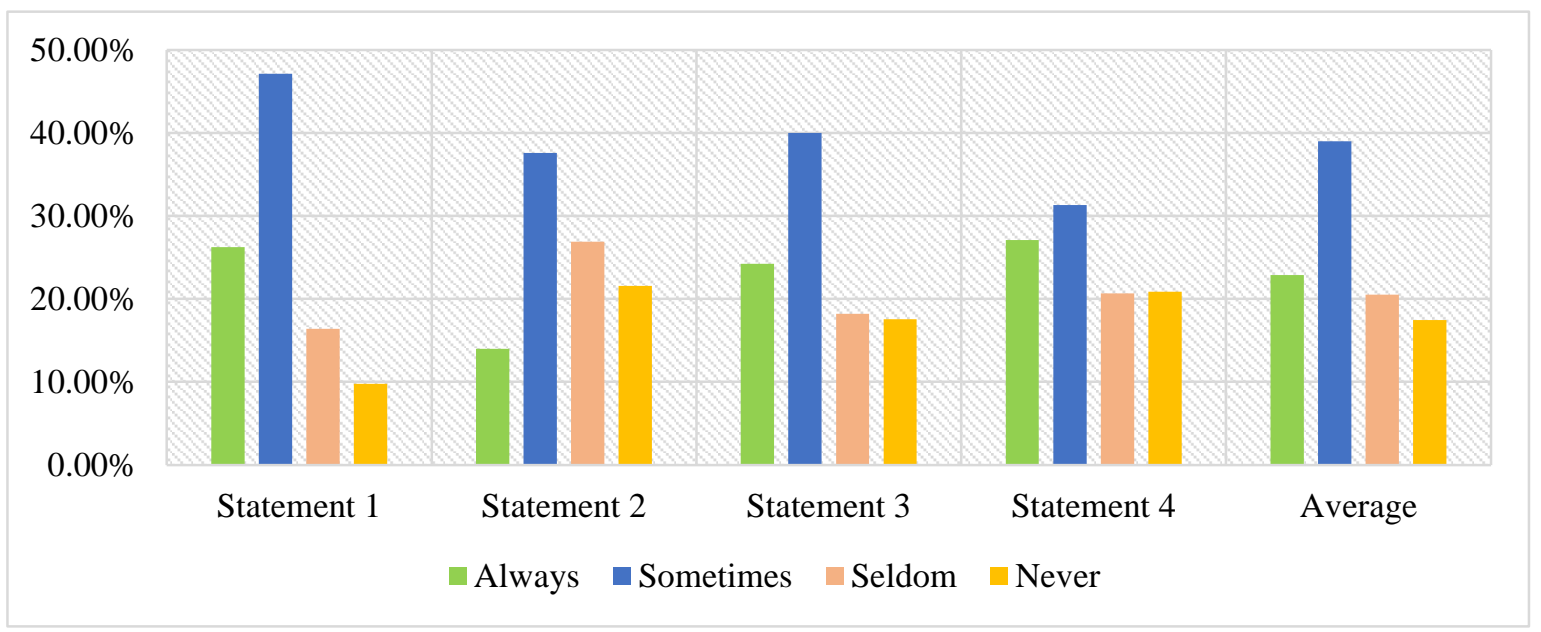

Figure 4 Cultural Behavior

Based on the results of data analysis, students SMP in Sumbawa already has the ability to understand cultural differences, has an awareness of cultural differences, has the motivation to work with people from other ethnic groups and students have the ability to make verbal and nonverbal adjustments when interacting with other people. in a multicultural situation. The number one predictor of success in today's borderless world is not IQ, not resume, and not even skills. This is CQ, a powerful skill that has been shown to increase effectiveness in working in culturally diverse situations. And CQ is something that anyone can develop and learn (David Livermore, 2011).

Cultural intelligence (CQ) explicitly introduces the concept of mindfulness as a key component that links knowledge with behavioral capabilities. Thus, cultural intelligence is an attribute possessed by individuals that allows them to be more effective in cross-cultural 
interactions. Effective ability in cross-cultural interaction allows the diversity of cultures, ethnicities, religions, beliefs, and customs to be the capital and strength of Indonesia in building a harmonious society. Lack of cultural awareness and inadequate knowledge of cultural backgrounds directly hampers the learning competence of students. Therefore, it is very important to increase students' cultural awareness and develop their background knowledge about culture (Wang, 2018).

Referring to the scores obtained on each indicator of cultural intelligence, students' cultural knowledge is lower than other indicators. The low indicator of cultural intelligence will automatically have an impact on other indicators. There is a consistent pattern of relationships in which metacognitive CQ and cognitive CQ predict cultural judgment and decision making; Motivational CQ and behavioral CQ predict cultural adaptation, and metacognitive CQ behavior and CQ predict task performance. Therefore, as far as possible all indicators of cultural intelligence can be improved. In addition, in the very diverse context of Sumbawa, teachers are required to have the ability to design and implement learning that leads to the process of developing cultural intelligence as a whole, namely through more student-centered learning. Kupris \& Hunter (2016) stated that students' CQ is positively correlated with cross-cultural competence and students' previous experiences. In the current era of globalization, intercultural encounters are a serious threat to students. To cope with global realities, students must be given awareness of a variety of knowledge, so that they have broad competencies in global knowledge, including cultural aspects (Hakim et al., 2018).

Around the world, the twenty-first century middle class spaces are based on growing cultural diversity (Kazanjian, 2019). The concept of cultural intelligence (CQ) has been introduced to understand why some individuals are more effective than others in dealing with culturally diverse situations (Jassens, M., \& Cappellen, T., 2008). The cultural behavior of students in the classroom can be illustrated by the willingness to mingle and share experiences and knowledge with other students on the basis of trust. Sharing knowledge must be based on trust, students need to develop trust that their friends are not only competent but the knowledge they convey is true (Annansingh, 2016). However, cultural intelligence can be improved by developing its dimensions. The four CQ factors are complex attributes, consisting of metacognitive, cognitive, motivational, and behavioral. Metacognitive CQ reflects the mental ability to acquire and understand cultural knowledge. Cognitive CQ reflects general knowledge and the structure of knowledge about culture. Motivational CQ reflects the individual's ability for learn and function in intercultural situations. Behavioral CQ reflects an individual's ability to perform appropriate verbal and nonverbal actions in interactions with diverse cultures (Davied Livermore, n.d.).

\section{CONCLUSION}

In the context of cultural diversity, cultural intelligence is needed, especially in a global situation. To increase the harmony and openness of students to diversity, cultural intelligence is the right solution to be developed in schools. Cultural intelligence is a skill that needs to be developed in schools. Based on the results of the study, it can be concluded that junior high school students in Sumbawa can be said to have the ability to understand differences well, have good knowledge of cultural differences, have the motivation to work with different ethnicities, and have the ability to adapt to multicultural situations. The cultural intelligence of the students in this study can be a reference for schools in Sumbawa to develop the learning process in a more democratic direction. Thus, the learning process in the classroom must lead to the formation of better cultural intelligence of students.

\section{RECOMMENDATION}

Cultural intelligence is a competency that must be taught to students in a multiethnic society, so it is recommended to policy makers, teachers, and school principals to maximize 
the increase in student intelligence so that tolerance and harmony among students in a multicultural society can be achieved properly.

\section{REFERENCES}

Ang, S., Van Dyne, L., Koh, C., ng, K. Y., Templer, K. J., Tay, C., \& Chandrasekar, N. A. (2007). Cultural Intelligence: Its Measurement and Effects on Cultural Judgment and Decision Making, Cultural Adaptation and Task Performance. Management and Organization Review, 3(3), 335-371. https://doi.org/10.1111/j.1740-8784.2007.00082.x

Annansingh, F. (2016). Academics 'perception of knowledge sharing in higher education. International Journal of Educational Management.

Gustina, Ananda, A., \& Kosasih, A. (2019). Factors in Using Speech Method in Social Subject. 178(ICoIE 2018), 1-3.

Hakim, F. N., Kartono, D. T., \& Demartoto, A. (2018). Internalization multicultural education for the prevention. 2(1), 129-138.

Iskandar, S. (2013). Inter-Ethnic Conflict Samawa and Bali in Sumbawa, Indonesia. 3(20), 40-45.

James, M, \& Wulandari, M., P. (2014). Cultural intelligence key to future of AustraliaIndonesia relationship. Artikel online pada The Conversation Academic Rigour Journalistic Flair.

Janssens, M, \& Cappellen, T. (2008). Contextualizing Cultural Intelligence: the Case of Global Managers. In Handbook of Cultural Intelligence, pp 356.

Kazanjian, C. J. (2019). Culturally responsive secondary education: exploring cultural differences through existential pedagogy cultural di ff erences through existential pedagogy. Multicultural Education Review, 11(1), 20-36. https://doi.org/10.1080/2005615X.2019.1567094

Kupris, L., H, \& Hunter, J. (2016). Developing Students' Cultural Intelligence Through an Experiential Learning Activity: A Cross-Cultural Consumer Behavior Interview. https://journals.sagepub.com/doi/abs/10.1177/0273475316653337.

Livermore, David. (2011). The Cultural Intelligence Difference.

Livermore, Davied. (n.d.). Conceptualization of Cultural Intelligence. In Book Chapter (Issue 62 , pp. 1-12).

Mansuri, L., Bombay, A. P.-, \& Training, T. (2014). Education Cultural Intelligence ( CQ ): A Pathway for Building Peace ABSTRACT KEYWORDS : 2277, 32-34.

Menon, S., \& Narayanan, L. (2015). Cultural Intelligence: New Directions for Research in Asia. Asian Social Science, 11(18), 193-202. https://doi.org/10.5539/ass.v11n18p193

Moore, B. A. (2018). Developing Special Educator Cultural Awareness Through Critically Reflective Professional Learning Community Collaboration (pp. 243-253). SAGE.

Ramis, M., \& Krastina, L. (2010). Cultural Intelligence in the School. Revista De Psicodidactica, 15(2), 239-252. https://doi.org/10.1387/RevPsicodidact.818

Smith, W. I., Evans, C. L., \& Florida, A. (2010). 360 Approach To Assessing Cross-Cultural Intelligence: Use of Film. Journal of Instructional Pedagogies, 3, 0-9. http://jupapadoc.startlogic.com/manuscripts/09424.pdf

Suharli, S., Andriani, N., Fatmawati, F., Suryani, E., \& Merdekawati, A. (2021). The Implementation of Social Studies Learning Model Based on Cultural Intelligence. Proceedings of the 2nd Annual Conference on Education and Social Science (ACCESS 2020), 556(Access 2020), 431-436. https://doi.org/10.2991/assehr.k.210525.122

Suharli, Supriatna, N., Maryani, E., \& Komalasari, K. (2019). Profile Of Teacher's Strategy In Improving Student's Cultural Intelligence. In Proceeding: International Conference on Social Science and Character Educations (IcoSSCE 2018) and International Conference on Social Studies, Moral, and Character Education (ICSMC 2018). (Vol. 323).

Wachira, P., \& Mburu, J. (2017). Culturally Responsive Mathematics Teaching and 
Constructivism: Preparing Teachers for Diverse Classrooms. Multicultural Learning and Teaching, 1-8. https://doi.org/10.1515/mlt-2016-0023

Wang, G. (2018). On the Strategies of Enhancing Students ' Cultural Awareness in College English Teaching. 11(12), 116-120. https://doi.org/10.5539/elt.v11n12p116 